\title{
SOCIAL ENTREPRENEURSHIP AND WHAT DOES IT MEAN FOR MANAGEMENT OF CONSUMER BEHAVIOR
}

\author{
Elvin Omarov \\ Honorary Research Fellow, Fil. Dr. Jan-U. Sandal Institute, Finstadjordet, Norway \\ e-mail: omarovelvin@gmail.com
}

Received: 23 July, 2020 Accepted: 30 July, 2020 Published: 24 August, 2020

\begin{abstract}
The most important factor in the success of an organization on the market is to study and satisfy the needs of the end customer of the product/service. The exclusion and insufficient consideration of the interests of consumers of social services is not only equivalent to the imposition of these services, but also leads to a significant increase in costs in the implementation of measures aimed on improving the quality of life of the population. By including these interests as the forces of self-movement of the population in the service mechanism, it is necessary to create conditions for the selforganization of citizens, who are choosing themselves the services they need and the ways services are provided. However, neither state nor companies are ready, due to a number offactors, to solve this problem. Under these conditions, there is an opportunity for the development of socially oriented enterprises. The aim of this work is to study the evolution of social entrepreneurship in the world space. To achieve this goal, the concept of "social entrepreneurship" was clarified, the practice of developing social entrepreneurship worldwide was studied, periods of development of social entrepreneurship were identified, and the existing Ukrainian experience in this matter was presented. The purpose of this article is to analyse works devoted to the study of social entrepreneurship: the definition of the conceptual framework, its essence and concept; identifying characteristics of its influence on consumer behaviour management, signs and characteristics of social enterprises; types and motives of social entrepreneurs.
\end{abstract}

Keywords: Entrepreneurship, Social entrepreneurship, Management, Consumer behaviour, market

JEL classification: A14; B20; M10; O35

Citation:

Omarov, E. 2020. Social entrepreneurship and what does it mean for management of consumer behavior. Access journal, ACCESS Press, 1(2): 86-102, https://doi.org/10.46656/access.2020.1.2(1)

\section{INTRODUCTION}

Social entrepreneurship is becoming popular all over the world. It occupies a place in line with such universally recognized phenomena as non-profit initiatives, charity, and social responsibility. The existence of social problems is an inalienable attribute of any society, the reason for this is the impossibility of providing all members of society with equal opportunities for self-realization in all spheres. In social entrepreneurship, a person places higher demands on the ratio of economic efficiency and social justice, as a result of which social entrepreneur decides to independently deal with a problem, which is a kind of annoying factor to the society.

Being a promising and fast-growing area of research, the concept of social enterprise is still insufficiently studied, which is confirmed by a large number of theoretical and limited number of empirical studies in this area. The concept of social entrepreneurship is multifaceted and reflects a wide range of its inherent tasks and features. Scientists continue to study the entrepreneurial process, entrepreneurial behaviour and consider the social needs in social entrepreneurship. 
The British entrepreneur Florence Nightingale in the nineteenth century helped to improve conditions in the hospital during the Crimean War, thereby reducing the mortality rate, her compatriot social entrepreneur Andrew Moson received the title of peer in 2007 for his work on economic and social renewal and improvement of urban areas. He was the author of the book "Social Entrepreneur" and the manager of the company "Andrew Moson and Partners", which spreads his experience.

The term "social entrepreneurship" appeared in the academic world in the 1990s thanks to the efforts of researchers Bill Drayton, company founder Ashok and Charles Leadbeater. In addition, in 1991 S. Wadad published a short article on social entrepreneurship (Certo \& Miller, 2008).

Jan-Urban Sandal has being studying phenomena of social entrepreneurship over decades and is directing Fil. Dr. Jan-U. Sandal Institute, one of the main directions of research of this institute is social entrepreneurship. Jan-Urban Sandal defined social entrepreneurship as a special form of management, which purpose is to run a production function in such a way as to ensure the increase of value for all the participating parties in that function (Sandal, 2004).

Social entrepreneurship as a profession and field of study was presented by Gregory Dees, director of the Centre for the Development of Social Entrepreneurship at Duke University. He noted that social entrepreneurship is distinguished by the dominant role of social change, calling it "striving for a result associated with a mission" (Dees, 2007).

Social entrepreneurship has been recognized by the public sector, scientific interest in this area has become noticeable since 1998 and has been actively increasing over time (Nicholls \& Cho, 2006).

Michael Young played a major role in the development of social entrepreneurship. Harvard professor Daniel Bell named Yang the most successful entrepreneur in the world in the field of social initiatives, thanks to his role in setting up more than 60 organizations around the world, including several UK social entrepreneurship schools.

A successful example of social entrepreneurship is the activity of the "Grameen Foundation" under the leadership of Muhammad Yunus, who formulated the image of social business in its current sense. The essence of his project is to create and subsequently replicate the new institutional model of microfinance, which is an effective tool to combat the problem of poverty and stimulates the economic activity of the relevant segments of the population.

\section{Methodology}

Descriptive and analytical research design is followed in the study. The major concern is to review of social entrepreneurship, its practice and development. In addition, was studied the influence of social entrepreneurship on effectivity of consumer behaviour management. 


\section{Results}

The advantages of interest in studying social entrepreneurship are its solution of social problems using innovative technologies (Thompson et al, 2017) and the creation of hybrid enterprises, where innovative entrepreneurial activity is guided by a strategy of ensuring both social and economic growth. This activity is different from the activity of entrepreneurs of traditional entrepreneurship of a public and private nature (Wallace, 1999).

In developing countries, social entrepreneurship, using innovative and cost-effective methods, contributes to solving basic social problems, such as reducing poverty rates and eliminating gender inequalities (Chell et al., 2010).

In underdeveloped countries, where traditional state initiatives are not able to satisfy the entire social deficit, social entrepreneurship has a clear application. Problems are exacerbated in a social context, characterizing massive inequalities in education, housing, and form high unemployment and poverty rates. Under these conditions, social entrepreneurs play the role of agents of change by addressing these problems by adopting a mission to create and maintain social value and use new opportunities to provide this mission (Urban, 2013).

The concept of social entrepreneurship is constantly criticized, as it is difficult to identify problems for its research (Mair \& Martí, 2006; Weerawardena, Mort, 2006; Choi \& Majumdar, 2014). Different interpretations of social entrepreneurship may be associated with the consideration of entrepreneurship and society (Steyaert \& Katz, 2004).

The author argues that the business space may depend on discursive, social and geographical factors. The discursive factor focuses on the cultural, environmental, social and economic dimensions of entrepreneurship. Social - considers entrepreneurship as a social process that includes participants and stakeholders. The geographical factor is the measurement of the spatial categories of social entrepreneurship between regions, peoples and surroundings. The conceptual foundations of social entrepreneurship are determined by (Austin et al., 2006):

- Market failures, that create various business opportunities in the provision of public goods;

- Mission, as a fundamental distinguishing feature of social entrepreneurship;

- Resource mobilization processes, aimed at creating a social goal and consisting in making a profit;

- Formation of hybrid forms of social enterprises;

- Efficiency of social impact.

Social entrepreneurship can enrich more traditional areas of research, such as structuring theory, institutional entrepreneurship and social movements (Mair, Martí, 2006). Supporters of the theory of social actions believe that it can be used to understand and explain the most diverse social phenomena from individual acts of individual behavior to large-scale socio-historical processes. The genesis and development of this theory are closely connected with the names of such sociologists as M. Weber, F. Znanetsky, and T. Parsons. 
In their studies, researchers note the dynamic, disequilibrium aspects of the environment in which innovations take place in social entrepreneurship.

The concept of the self-organization of Schumpeter's theory stands out, arguing that the success of the market system lies not in effectively achieving static optimal equilibrium, but in the ability to make dynamic changes in technology and achieve dynamic growth through such changes (Tapsell \& Wood, 2010). Thus, the historical and cultural context in which innovations occur is important for the development of social entrepreneurship.

As a direction of social entrepreneurship research, other authors point out achieving a sustainable competitive advantage in the implementation of a social mission, which is the main result of organizing social entrepreneurship (Weerawardena \& Mort, 2001). At the same time, they note that social entrepreneurship should be modelled within the wider competitive environment in which this activity takes place (Weerawardena \& Mort, 2006). The studies emphasize that social entrepreneurship is a limited multidimensional construct, where the realization of the organization's social mission and its commitment to sustainability is necessary, while at the same time it should be strongly influenced by a dynamic environment.

The concept of social entrepreneurship can be complex, combine several sub-conceptions: social enterprise, social entrepreneur, social significance, market orientation and social innovation (Choi \& Majumdar, 2014).

This concept is based on the theory of the researcher Gallie, which was putted forward in 1956. In it, author examines entrepreneurship by the example of the "art" concept and defines its seven main criteria: compatibility, internal complexity, describability, openness, aggressiveness and defensiveness, originality of an instance and progressive competition (Gallie, 1956).

Thus, understanding of social entrepreneurship is forming cluster concepts raised in the researches by authors all over the world. The analysis of articles revealed controversial conceptual differences that influence the definition of social entrepreneurship. Social entrepreneurship can be viewed as a model of political transformation, process or activity of entrepreneurial behavior, founder of social initiatives, creating a social enterprise and interest in material results.

Numerous studies of the essence of social entrepreneurship revealed shows that there is still no single definition of the concept of "social entrepreneurship". The literature review is fragmented and there is no single consistent theoretical framework. The conceptualization of social entrepreneurship does not take into account the unique characteristics of social entrepreneurs and the context in which they should work.

\section{Concepts of social entrepreneurship}

The definitions of social entrepreneurship overlap with classical approaches to the analysis of entrepreneurship, as many scholars claim. The author emphasizes that the key word in the category of social entrepreneurship is "entrepreneurship", and "sociality" plays only a modifying role.

The key properties of entrepreneurship are the creation of value as a result of moving assets to a higher productivity area (Say); "Creative destruction" as a transformative activity (Schumpeter); search for changes 
and use of opportunities (Drucker). All this applies equally to both entrepreneurship and social entrepreneurship, each of which offers a new value (benefit), overcoming the well-established equilibrium (Batalina et al., 2007).

The researchers have already proposed a classification of definitions by social entrepreneurship: these definitions are inclusive and exclusive. Inclusive definitions include the elements: "the number of subjects, social ideas, opportunities and the system of organizations". Exclusive definitions are distinguished by a smaller number of listed elements (Swanson \& Zhang, 2010).

One of the main definitions of social entrepreneurship is the mission with the creation of social values, the study and formation of new opportunities and innovations with unlimited use of resources, as well as a high sense of responsibility for entrepreneurship (Dees, 1998).

Many authors believe that "social entrepreneurship encompasses activities and processes that determine and use opportunities to improve the well-being of society by creating new enterprises or managing existing organizations in an innovative manner" (Zahra et al., 2009).

Authors S. Bacq and F. Janssen consider social entrepreneurship as a multidimensional and dynamic model, previously proposed by Gardner, combining interrelated elements: social entrepreneur, business process, social organization, reflecting its characteristics and development strategy and the environment (Bacq \& Janssen, 2011).

Within the framework of economic theory, social entrepreneurship identifies the main characteristic - an innovative component due to the fact that entrepreneurship is defined as the process of creating something new that has value, or as a type of management based on the innovative behavior of the managers of the enterprise; and a social entrepreneur is defined as a self-organizing subject of economic activity.

The absence of a unifying paradigm in the field of social entrepreneurship has led to the formation of a large number of its definitions. Currently, researchers continue to actively explore its conceptual framework, explore the essence of social entrepreneurship, discuss the contribution of social enterprises to the creation of social wealth, and explore the typology of search processes, which leads to the discovery of opportunities for creating new social enterprises.

Social entrepreneurship is based on the notion of "entrepreneurship", that is, initiative self-directed activity (self-organizing in essence) of citizens, aimed at making a profit or personal income, carried out on its own behalf, under its property responsibility or on behalf of and under the legal responsibility of a legal entity. Social entrepreneurship is an innovative activity, initially aimed at solving or mitigating the social problems of society on the basis of self-sufficiency and sustainability (Arai \& Burmistrova, 2014).

The study of various definitions of social entrepreneurship (Austin, 2006; Nicholls, 2009) allowed to take as a basis a definition that combines the definitions of many authors: social entrepreneurship is an entrepreneurial activity or a process that creates the possibility of a hybrid partnership, aimed at establishing social responsibility and solving problems in the social protection system, ensuring systematic social changes 
and generation social values by the creation of new organizations or innovative ways to manage already existing organizations.

A feature of social entrepreneurship is the way in which it works, that is, the forms and mechanisms of its implementation. Here the central role is occupied by the concepts of "entrepreneurship" and "innovation". The task of the social entrepreneurship is to solve social problems by an innovative method, by creating a selfreplicating mechanism for providing social benefits. In essence, this is the source of the synergistic effect of the interaction of the entrepreneur's existing resources and the needs of purchasers of social services.

The result of socially oriented entrepreneurial activity is social innovation (Nyssens, 2006), that is, a new way to solve a social problem. The significance of social innovation - its value - is determined by the ability to meet the social needs of the recipient of the service in a new, convenient for him/her, way. The most important result of the social entrepreneurship is the growth of social value added by innovation - improving the quality of life of the population due to:

- Compliance (achievement) of the life standards minimum quality;

- Finding new ways to solve social problems;

- Synergistic effect of the interaction of resources and self-organization of consumers.

The borderline of social entrepreneurship (between entrepreneurship and charity) necessitates the allocation of criteria inherent to the social entrepreneurship as a phenomenon. These criteria are (Golubovic \& Bullain, 2006):

- Social mission;

- Entrepreneurial approach;

- Innovation (innovation in solving social problem, by new combination of resources);

- Replicability;

- Self-sufficiency and financial sustainability.

The starting point in such business development is a social problem that the entrepreneur is trying to solve. To achieve his/her goals, entrepreneur must be able to see the situation in a new way and use new opportunities, effectively use available resources, and possess the necessary activity and motivation.

Many social problems could not be solved within the framework of standard approaches. Therefore, the success of a socially oriented business is largely based on the use of an innovative (sociocultural) approach. This refers to the use of new approaches in solving a specific social problem, the use of a new combination of resources, launching of a new product or service on the market.

The scale of a business is one of the conditions for its success (Swanson \& Zhang, 2010). Therefore, one of the criteria of success for social entrepreneurship is the possibility of its replication (maximum development within the borders of the current territory, coverage of new territories). A successful business should provide a constant cash flow, be self-sustaining and financially sustainable. A socially oriented business involves a certain balance between social objectives and the commercial component. Money here is not an end in itself, 
but a means for achieving the social goals of the organization. Profits are mainly reinvested basing on the goals into a business or local community, and do not flow fully into the pockets of shareholders and owners.

The scope of the potential of the social entrepreneurship is the non-profit sector (Stryjan, 2006). The purpose of the activities of non-profit organizations is the satisfaction of primarily domestic and spiritual needs. Primary areas of activity for non-profit organizations are culture, healthcare, legal and educational services, science, and sports. These are areas of activity that are insufficiently financed by the state. In turn, purely commercial organizations are not ready to invest in these areas of activity due to the economic unprofitability of investments.

On the contrary, the goal of the activities of social enterprise is to alleviate the existing social problems by using mainly the mechanism of self-organization and innovation. Profit is not the purpose of these organizations. Work is carried out on the border of charity and profitability. The proceeds are directed to the further development of organizations.

Using the resource of self-organization allows not only reducing the costs of social services in comparison with existing commercial organizations (for example, nanny / nursing agencies), but also improves the quality of life of the population by identifying and meeting the needs of the population for those services that do not appear within the framework of the existing social infrastructure (for example, the provision of services for the delivery of products and medicines to the home).

Thus, the role of social entrepreneurship in the economy is to increase the overall economic efficiency by introducing into the economic turnover those resources and mechanisms that were not previously used as such (for example, a more developed level of property management culture). This applies to unused material and human resources, as well as new combinations of available resources.

\section{Non-governmental organizations and social enterprises}

In the early stage of studying the phenomenon of social entrepreneurship, researchers identified two types of social enterprises: based on pure philanthropy and based on pure commerce. Somewhat later, C. Alter proposed the theory of hybrid organizations (Popov \& Veretennikova, 2016). Features of various models of social organizations are reflected in tab. 1. Unlike a socially responsible business, the motive of a social entrepreneur is a social effect, a solution to a social problem.

Thus, the differences between the non-profit sector, commercial sector, socially responsible business and the social enterprise can be identified based on objectives, reporting and distribution of profits. The goal of the social enterprise and non-profit organization is to fulfil the mission, the profit is reinvested in the realization of the social mission, that is, the solution of the socially significant problem; reporting is carried out to partners and stakeholders. In contrast to this, for a traditional commercial enterprise the main and only goal is to make a profit, which is distributed among the participants and reporting is carried out to shareholders. 
Table 1. Features of different models of social organizations

\begin{tabular}{|l|l|l|l|}
\hline \multicolumn{1}{|c|}{ Organizations } & \multicolumn{1}{|c|}{ Based on pure charity } & \multicolumn{1}{c|}{ Hybrid } & \multicolumn{1}{c|}{$\begin{array}{c}\text { Based on pure } \\
\text { commerce }\end{array}$} \\
\hline Motives & \multicolumn{1}{|c|}{ Good will } & \multicolumn{1}{c|}{ Mixed } & \multicolumn{1}{c|}{ Personal interest } \\
\hline Methods & Determined by the mission & $\begin{array}{l}\text { Determined by a combination of mission } \\
\text { and market }\end{array}$ & $\begin{array}{l}\text { Determined by the } \\
\text { market }\end{array}$ \\
\hline Goals & Creating social value & Creating social and economic value & $\begin{array}{l}\text { Creating economic } \\
\text { value }\end{array}$ \\
\hline Purpose of income & $\begin{array}{l}\text { Directed directly to the } \\
\text { implementation of the NGOs } \\
\text { mission (determined by the law } \\
\text { or by organization's policy) }\end{array}$ & $\begin{array}{l}\text { Reinvested on the implementation of the } \\
\text { mission, or on operating expenses and/or } \\
\text { retained for the expansion and } \\
\text { development of the business (can be } \\
\text { partially redistributed among the } \\
\text { participants) }\end{array}$ & $\begin{array}{l}\text { Distributed between } \\
\text { shareholders and } \\
\text { the owners }\end{array}$ \\
\hline
\end{tabular}

The experience of social entrepreneurship shows that solving social problems on the basis of entrepreneurship is often more effective than using standard government mechanisms or non-profit organization. This thesis underlies the theory of hybrid non-profit organizations. The basis of the activities of organizations of this type are the following postulates:

- Combination of goodwill and personal benefit to the leadership of the organization;

- Working methods are determined not only by the social mission, but also by market conditions;

- Product (service) being created represents not only social but also economic value;

- Profit is fully or partially invested in the further expansion of the business (depending on the organizational and legal form of the enterprise).

If the first part covers the expenses of social organization, is limited in time and does not fundamentally change the nature of the work of social organization, then the second type is systematic in nature, is associated with ongoing operational activities and can serve as the basis for becoming a social enterprise. According to $\mathrm{K}$. Alter, the criteria for attributing an enterprise to an non-profit organization or a social enterprise are not so much the scale of the profitable activity, its share in the total income structure or the amount of personnel employed in it, but whether the enterprise functions and is managed "as a business" (Defourny \& Nyssens, 2010). The latter means that income-generating activities are strategically designed for the production of social / economic benefits focused on long-term goals and are constantly being reproduced. Features of motivation and distribution of income in hybrid organizations is given in tab. 2 .

Table 2. Features of motivation, responsibility and distribution of income in different types of organizations

\begin{tabular}{|c|c|c|c|c|c|}
\hline \multicolumn{6}{|c|}{ Spectrum of hybrid organizations } \\
\hline Traditional NGO & $\begin{array}{l}\text { NGO with } \\
\text { profitable } \\
\text { activities }\end{array}$ & Social enterprise & $\begin{array}{l}\text { Socially } \\
\text { responsible } \\
\text { business }\end{array}$ & $\begin{array}{l}\text { Company which } \\
\text { is applying social } \\
\text { responsibility to } \\
\text { its activities }\end{array}$ & $\begin{array}{l}\text { Traditional } \\
\text { profitable } \\
\text { enterprise }\end{array}$ \\
\hline \multicolumn{3}{|c|}{$\begin{array}{l}\text { motivation, which is determined by the mission; } \\
\text { responsibility to stakeholders; } \\
\text { expenses }\end{array}$} & \multicolumn{3}{|c|}{$\begin{array}{l}>\text { motivation on generating profit; } \\
>\text { responsibility to shareholders; } \\
>\text { profit is distributed among shareholders }\end{array}$} \\
\hline
\end{tabular}


Social entrepreneurship is a business aimed on solving (mitigating) social problems (Nyssens, 2006). Entrepreneurs working in this area have a double task: first, to satisfy the needs of the population for those social services that cannot be provided in a quality manner within the framework of the existing system of organizations that make up the social infrastructure; secondly, to improve the quality of life of certain categories of citizens due to their inclusion in the labour activity, if for a number of reasons they were turned off from it (retirement, disability, etc.).

Social enterprise as well as purely commercial structures operate in a competitive market. Therefore, it is necessary to consider the specific features of the competitive environment of social entrepreneurship. One of the competitors of social entrepreneurs is the state, more precisely, the state system of social support for the population. As part of the ongoing social and economic policy, the state guarantees that certain categories of citizens to receive social support (the provision of free medical care, social services are disabled for citizens, etc.). However, for a number of reasons (economic downturn, economic crisis), the state cannot provide social protection to all citizens in need.

The lack of resources, personnel, as well as the lack of necessary services in state (municipal) organizations does not allow the provision of social services with the required level of quality. Moreover, here for a socially oriented organization, emerges the possible market, in which enterprise can develop. A feature of a socially oriented organization is its functioning at the intersection of charity and entrepreneurship. Consumers of goods and services of these organizations are people with low income. Therefore, the competitive advantage of social entrepreneurs, compared with purely commercial organizations, is the lower price of manufactured goods and services provided.

Close cooperation with the authorities allows socially oriented organizations to set lower prices by reducing individual items of expenditure (lower rental rates, provision of municipal premises for use free of charge, subsidies for separate expenses, tax holidays) (Arai \& Burmistrova, 2014).

The competitive environment in the field of social entrepreneurship has a number of features. First, a competitor may be a state represented by state institutions. However, in this case, competition is not an alternative one (either enterprise or the state), but an additional one.

Due to various factors, budgetary institutions cannot satisfy all needs of the people and, therefore, provide only basic services to citizens. As the reason, entrepreneurs may offer to the market new social services and even interact with government agencies and state institutions (for example, to offer of nursing services in hospitals). Competition with purely commercial organizations is possible based on lower costs of goods and services, provided while they retain their proper quality.

\section{Features of the consumer behavior management in socially oriented organizations organizations}

Non-commercial product. From the standpoint of social marketing, the product represents the desired behaviour and the associated benefits from the implementation of this behaviour. The very concept of 
"behaviour" also includes material objects that can be sensed, proposed in order to maintain and promote the planned changes in the behaviour of the target audience (David \& Day, 2011). With reference to a socially oriented business, examples of traditional three levels of a product (basic product, real product, expanded product) may look as it is presented in tab. 3 .

Table 3. Examples of three product levels in a socially oriented business

\begin{tabular}{|l|l|l|}
\hline \multicolumn{1}{|c|}{ Basic Idea of the Product } & \multicolumn{1}{c|}{ Pctual Product } & Expanded product \\
\hline \multicolumn{3}{|c|}{ "Healthy Lifestyle" } \\
\hline Longevity and health & Quit Smoking & Trainings \\
\hline Reducing the risk of heart attack & Measuring blood pressure regularly & Special equipment (tonometer) \\
\hline Protection against preventable diseases & Strengthen children's immunity in time & Wallet-sized immunization card \\
\hline $\begin{array}{l}\text { Natural immunity for children and } \\
\text { nursing mothers }\end{array}$ & Breastfeeding for at least 6 months & $\begin{array}{l}\text { Home Consultation with a medical } \\
\text { specialist }\end{array}$ \\
\hline \multicolumn{3}{|c|}{ Project "Environmental Protection" } \\
\hline Improving water quality & Growing native plants only & Landscaping work \\
\hline $\begin{array}{l}\text { Protection of children, pets and wildlife } \\
\text { from toxic chemicals }\end{array}$ & $\begin{array}{l}\text { Careful study of instructions and } \\
\text { measures of pesticide use }\end{array}$ & $\begin{array}{l}\text { A magnifying glass attached to a } \\
\text { pesticide container }\end{array}$ \\
\hline
\end{tabular}

The price for the product/service of social enterprise. A special feature of pricing in such conditions is the consideration of consumer motives. According to Hermann, consumer behavior is impacted by four factors: benefits, costs; other consumers; self-efficacy (Hermann, 2015). In accordance with these factors, while purchasing a product, the buyer always faces the need to make a choice - or make an exchange - between benefits and costs. In the private sector, costs are usually expressed in monetary and temporal terms, but social organizations can often include pain, embarrassment or loss of self-esteem, guilt, and many other nonmonetary costs associated with making difficult decisions.

Distribution of the product/service in social enterprise. A very important marketing tool is the place of purchase of the product. In marketing for social enterprises, this is the place where and when the target audience can get the opportunity to show the desired behavior, to acquire the required material objects and associated services. The main purpose of creating and developing a distribution system for a non-commercial product is to develop strategies that will make it more convenient and pleasant, as far as possible, to purchase a non-commercial product. This marketing tool involves the development of logistic channels for distribution, delivery of the finished product from the place of production to the consumer. Marketing channels are the set of measures (independent or dependent) that allow a product / service produced / provided by a manufacturer to reach its consumer.

In some cases, the funding of social activities is provided through raising the necessary funds through donations, grants, social procurement, etc., thus, organization have to deal with two interrelated tasks in the field of marketing: activities to raise the necessary funds and resources; usage of attracted funds and resources in accordance with the mission of the organization.

Maintaining a balance between the interests and expectations of these two groups is often a very difficult task. For example, donors, as well as many organizations that provide intermediary services on an unpaid basis, may require that the funds they provide (any resources) be used to provide services to a particular group 
of the population, while the leaders of the organization believe that their programs should be aimed on another group of people (Morris \& Hirschman, 2012). In addition, "third parties" are often interested in the activities of the organization - for example, health insurance companies, politicians, former clients who, one way or another, may or may not support the activities of the organization, as well as the media (Morris \& Hirschman, 2012).

Ideally, participants in the marketing channel of any organization should strive to coordinate with each other their goals, plans and programs, thus ensuring the maximum efficiency of the overall distribution system. That is, the maximum effect of the distribution channel's work is achieved if the participants maintain certain partnership relations. Partnerships are based on close relationships, cooperation, trust and fulfillment of obligations by the participants of the marketing channel. The development of such relations leads to the creation of a solid marketing channel, in which the boundaries between its participants disappear.

Promotion of a non-commercial product/service. The main goal of product promotion in marketing for social enterprises is to make sure that the target audience knows about the offer, wants to get certain benefits and is ready for action (Wallace, 1999). For this reason, depending on the stage at which the target audience resides, the tasks of developing communications are different. Here it is necessary to understand that the behavior of a high degree of involvement does not change instantly, but changes over time. Therefore, in the marketing literature, it is proposed to break the long process of "behavior change" into several stages, as it is shown in tab. 4.

Table 4. Tasks of communication development depending on which stage the target audience is on the path of "behavior change"

\begin{tabular}{|l|l|}
\hline \multicolumn{1}{|c|}{ Stage } & \multicolumn{1}{|c|}{ The task for building communications } \\
\hline $\begin{array}{l}\text { The preliminary stage, when members of the target audience do not } \\
\text { think about the behavior that enterprise wants to change. This } \\
\text { happens if they are not aware of the behavior, or they know, but for } \\
\text { some reason it is unacceptable to them. }\end{array}$ & $\begin{array}{l}\text { Informing the target audience about alternative actions } \\
\text { and attempts to interest it. }\end{array}$ \\
\hline $\begin{array}{l}\text { The stage of reflection, when the beneficiaries weigh the costs and } \\
\text { benefits of the proposed exchange, and are interested in the opinions } \\
\text { of others and form an idea of whether they can adhere to this } \\
\text { behavior. }\end{array}$ & $\begin{array}{l}\text { Report on the positive consequences of choosing certain } \\
\text { behaviors and the formation of role models. }\end{array}$ \\
\hline $\begin{array}{l}\text { The stage of preparation and action, when the beneficiaries think } \\
\text { over their new behavior and are ready to act. It is only need for them } \\
\text { to take the first step. }\end{array}$ & $\begin{array}{l}\text { Formation of motivations for performing an action at a } \\
\text { certain time and place and teaching them all necessary } \\
\text { skills. }\end{array}$ \\
\hline $\begin{array}{l}\text { Stage of maintaining behavior when beneficiaries perform a one- } \\
\text { time action, but there is a probability of returning to the old } \\
\text { behavior. }\end{array}$ & Communicate the rewards for repeating actions. \\
\hline
\end{tabular}

The development of a communication strategy includes two important stages: the creation of message and choosing channels for its dissemination, or bringing it to the target audience. The first stage of the communication strategy is to generate possible messages (Lepeyko \& Blyznyuk, 2016). There are different ways to create messages. One possible approach is to hold conversations with representatives of the target market and other influential persons (for example, through in-depth interviews or focus groups), listen to their wishes and reflect them in the message. Another way is to conduct brainstorming with the participation of key employees of the organization to generate different ideas. The third technique involves the use of some formal 
deductive scheme to identify possible communication messages. The second stage of the development of a communication strategy involves the choice of channels for disseminating a message.

The most frequently used communication channels in Ukraine for the promotion of a non-commercial product are advertising and PR, printed materials, and personal sales (Popov \& Veretennikova, 2016). The main functions of the promotion channels for socially oriented enterprise comes to the forefront of the fund raising function aimed at creating with potential donors a certain understanding of the organization and providing the donor with the necessary "encouraging" information to make a positive decision on financing the activities of NGOs.

Non-profit organizations use communication channels to create a positive image of the organization in the eyes of the public, in other words, to implement PR activities. Finally, by offering a certain message (from informing about past and upcoming events to presenting analytical materials and annual reports) and choosing a channel to bring it to the target audience, the organization seeks to make its activities more open and transparent for the external and internal functioning environment.

Usually, the mission and goals of non-profit organizations provide an understanding of who is the main target group of a given organization. The target audience in the broad sense is people whose behaviour can have a negative impact on themselves, those around them and society as a whole. Therefore, on the one hand, the target group of NPOs are the people touched by one or another social problem; on the other hand, these are all members of society who can support the organization and help solve a specific social problem (people of this category can become supporters or volunteers of the organization) or, on the contrary, contribute to the exacerbation of a social problem, etc. (Meyer \& Johnson, 2015).

Each segment of the target audience requires careful study, namely: all sorts of motives, reasons, incentives that serve as the basis for a certain behaviour of members of the audience. The success of a social entrepreneur depends largely on the extent to which the product it offers to the market is able to meet the needs of the consumer. In other words, an entrepreneur should be aware of market trends, look for new opportunities for the development of his/her organization (forecasting market trends, finding new markets, finding new ways to mitigate social problems, offering new services to consumers). In other words, a social entrepreneur is an innovator who is ready to work constantly on himself/herself and his/her organization in order to realize social mission.

Any organization at the first stage of its development requires certain investments. Sources of financing socially oriented enterprises can be own or attracted funds. In the absence of own financial development resources, the founders of the organization can attract funding from social venture capital organizations organizations that invest in the development of the non-profit sector of the economy. Social investment is one of the tools for implementing social programs of commercial companies and part of a company's strategy according to its mission. Social investment is a form of financial assistance allocated to the company for the implementation of long-term and, as a rule, partner social programs aimed on reducing social tensions in the 
regions where the company operates and raising the standard of living in various sectors of society. Return of funds is not a prerequisite. The following advantages (or motives) of social investments are distinguished:

- Fame;

- Improving the image of the company on the local and national level;

- Improvement of relations with investors, investment attractiveness of the company;

- Associating with a high quality or prestigious event;

- Attracting new employees and retaining old employees;

- Access to the labor market, including the highly professional one;

- Strengthened customer relationships;

- New partners are attracted;

- Tax breaks.

Evaluation of the effectiveness of social investments is an objective final judgment about the comparison of the benefits and costs, which are aimed at making an investment decision on their implementation and a financial decision on their financing. Indicators of the effectiveness of social investment are (Slaughter, Sinar, Highhouse, 2009):

- Social effect - characterizes the degree of satisfaction of the population with the quality of life;

- Social efficiency - an indicator that determines the improvement of people's living standards;

- Socio-economic efficiency - an indicator that gives an idea of the economic efficiency of investments in the social sphere, taking into account the social effect achieved;

- Economic efficiency - an indicator reflecting the economic efficiency of the project based on the ratio of results and costs.

Among the modern trends in the development of social entrepreneurship, the problem of its globalization comes to the fore (Choi \& Majumdar, 2014): global inequality in the distribution of wealth; growth of corporate social responsibility; market, institutional and government failures and the growth of distress in the social strata of the population; technological progress and general achievements that promote interest in the formation of investments, donations, partnerships with social organizations.

As the main social problems of society, which are necessary for solving by organizations of social entrepreneurship the following are distinguished: designing production in such a way that the surrounding nature is minimally damaged; helping people get out of the "pit of poverty"; finding use of the abilities of people in need of the workplace; improving the old and create new models suitable for solving social needs; solving social and environmental problems (Seelos \& Mair, 2005; Neck et al., 2009).

The main factor that distinguishes social entrepreneurship from the traditional one is the availability of social opportunities that entrepreneurs can use. Social and environmental problems provide an opportunity for entrepreneurial activities for social entrepreneurs. Solutions of social problems in healthcare, education, problems related to poverty of the population, environmental problems are alternative business spaces usage of new technologies and innovations. 


\section{DISCUSSION}

Social entrepreneur is identified as a person whose activities are aimed at exploiting opportunities to increase social wealth, creating new enterprises or managing existing organizations through innovative technologies. The concept of "social management" has been developed in scientific and educational literature on the sociology of management and the sociology of labour, social psychology and other social sciences. All this testifies the interdisciplinary nature of this field of research. However, the differences in interpretations of the basic terms, tasks, and problems of social management in various scientific and educational materials (Sandal, 2004) indicate that this area of knowledge is in its infancy, many questions remain little studied. In this regard, it is important before combining, synthesizing the achievements of different sciences, which will create a complex system of knowledge, to distinguish approaches from the point of view of each science, specify concepts and problems, and fill them with content related to the subject of a particular science.

This task also applies to the field of economics, where "social terminology" began to penetrate later than to other sciences (Dees, 2007) and where, respectively, there are more unexplored areas of social management, including CSR management, HR management, social entrepreneurship, social welfare state and others. Little studied questions become the subject of analysis of modern dissertation research in the field of economic sciences.

The proliferation of the new concept and phenomenon of social management can be found on many grounds, including the Ukraine. In vacancy announcements, as a rule, now not only the salary is noted, but also the presence of a social package. The positions of "social manager", "deputy director for social policy", "head of social facilities management" have appeared in a number of organizations and firms. In the classifier of educational specialties appeared specialty management (social and administrative). Social entrepreneurship, social responsibility of business, social assets of enterprises become the topics of scientific and practical seminars and conferences.

The increasingly active use of the concepts of socially responsible business, social entrepreneur, social package and others by economists and managers today testifies not so much about the impact of sociology on economics, but rather the development of new processes in the world practice of managing economic systems at the micro and macro levels. If sociologists tend to see elements of social management in different periods of history, then economists emphasize the novelty of the phenomenon itself, the objective character of its distribution as a new management style (Thompson et al, 2017).

The increasing role of human resource management in comparison with the management of material flows expands the functions of management, including in them as obligatory, social functions. This qualitatively changes management on all of its levels, and not just HR management. This is observed in the global economy as a whole, although new functions and characteristics of the new management style are spread unevenly across countries, regions and enterprises and continue to coexist with old forms and styles. 
Today, positions of both economists and sociologists are similar that a qualitatively new management is the management based on extending the principles of humanization, which is implemented in modern requirements for education and the practical work of managers. Nevertheless, sociologists pay more attention to the system of social relations, insufficient knowledge of the social problems of production management, increasing tendencies associated with the imbalance of social space, the threat of the destruction of individual ties with society, the impoverishment of spirituality and culture. While economists focus on increasing the role of human capital and the image of the organization, their impact on the economic efficiency of the organization and long-term competitiveness (Wallace, 1999).

This influence has formed new approaches to the principles of management formulated at the turn of the 20th and 21st centuries. In the new system of requirements for professional competencies of the manager, important elements are: ability to communicate; loyalty to employees; the creation of an atmosphere conducive to the disclosure of the abilities of staff, its ongoing training, job satisfaction; creating an atmosphere of honesty and trust as a new institutional framework in economic relations with customers, customers, partners. From this broad point of view, any modern manager can be called a social manager.

It would be wrong to assume that economic rationalism, associated with the desire to minimize costs and increase profits, is becoming a thing of the past, as an outdated management model, as the usual social management is crowded out. The expansion of the social functions of management is dictated by changes in the economic environment. Changes in the systems of resources, needs and technologies determine new ways to achieve the same economic goals. Therefore, the above-mentioned principles of the new management are just based on the requirements of economic feasibility and rational economic choice, associated with the optimization models of "cost-benefit", which guide economists and managers.

\section{CONCLUSION}

In this work, in order to study the evolution of social entrepreneurship in the world space, the following results were obtained.

First, it is substantiated that the formation and development of social entrepreneurship in different countries of the world is heterogeneous. Its features depend not only on the current institutional environment, but also on the historical conditions in which this type of activity is formed.

Secondly, it is shown that the model of European or American social entrepreneurship was transplanted into the developing countries of Latin America and Africa through the active support of international organizations and foundations.

Third, the drivers for the development of social entrepreneurship have been identified. It is shown that a necessary condition for the creation of socially oriented organizations is a political and legal environment that allows the creation of socially oriented organizations, and for their successful functioning and development, socio-cultural conditions and the presence of institutions involved in the study, training and support of social entrepreneurship are important. 
Fourth, the Ukrainian experience in the development of social entrepreneurship is presented, the conditions influencing the choice of the further path of development of social entrepreneurship are described.

The theoretical significance of this study lies in the systematization of research in terms of the development of social entrepreneurship in the global space. The practical significance lies in analysing the experience of introducing social entrepreneurship in various countries and studying the possibility of using social entrepreneurship to manage consumer behaviour.

\section{Acknowledgement}

This scientific article was created at the Fil. Dr. Jan-U. Sandal Institute, Finstadjordet, Norway under the supervision of Prof. Fil. Dr. Jan-Urban Sandal, Executive Director and Owner at the Fil. Dr. Jan-U. Sandal Institute (Excellence in Science and Education).

\section{Conflict of interests}

The authors declare no conflict of interest.

\section{References}

Arai, Iu. N., Burmistrova, T.A. (2014) Specific features of business models in social entrepreneurship. Rossiiskii zhurnal menedzhmenta (Russian Management journal), no. 21, pp. 125 -156.

Austin J., Stevenson H., Wei-Skillern J. (2006) Social or commercial entrepreneurship: Same, different, or both? Entrepreneurship: Theory and Practice, vol. 30 no. 1, pp. $1-22$.

Batalina M.L., Moskovskaya A.A., Taradina L.D. (2007) Review of the experience and concepts of social entrepreneurship, taking into account the possibilities of its application in modern Russia. Institutional problems of the Russian economy. WP1. NRU HSE, no. 2, pp. 21-36.

Bacq S., Janssen F. (2011) The multiple faces of social entrepreneurship: A review of definitional issues based on geographical and thematic criteria. Entrepreneurship \& Regional Development, vol. 23, no. 5 - 6, pp. 373 - 403.

Bolton, L.E., Warlop, L., Joseph, W.A., (2014) “Consumer Perceptions of Price (Un) Fairness", Journal of Consumer Research, vol. 29, no 4, pp. $43-57$.

Certo T., Miller T. (2008) Social entrepreneurship: Key issues and concepts. Business Horizons, vol. 51, pp. 267 - 271.

Chell E., Nicolopouloua R., Karatas M. (2010) Social entrepreneurship and enterprise: International and innovation perspectives. Entrepreneurship \& Regional Development, vol. 22, no. 6, pp. 485 - 493.

Choi N., Majumdar S. (2014) Social entrepreneurship as an essentially contested concept: Opening a new avenue for systematic future research. Journal of Business Venturing, vol. 29, pp. 363 - 376.

David, A., Day, G, (2011) Consumerism: Search for the Consumer Interest. New York: The Free Press.

Dees G. (2007) Taking Social Entrepreneurship Seriously: Uncertainty, Innovation, and Social Problem Solving. Society, vol. 44 , no. 3 .

Defourny, J., Nyssens, M. (2010) Conception of social enterprise and social entrepreneurship in Europe and the United States: convergences and divergences. Journal of Social Entrepreneurship, vol. 1, no. 1, pp. $32-53$.

Gallie W. (1956) Art as an essentially contested concept. The Philosophical Quarterly, vol. 6, no. 23, pp. 97 - 114.

Golubovic, D., Bullain, N. (2006) Perspective on regulatory issues for social enterprise development in CE. Materials of International Seminar Emerging Models of Social Entrepreneurship "Possible Paths for Social Enterprise Development in Central East and South East Europe”. OECD-Leed Programme. Zagreb, USAID, ISSAN. 
Harper, Levy S. (2016), "New in Consumer Analysis", Harvard Business Review, vol. 18, no 7, pp.129 - 140.

Hermann, S. (2015), Confessions of the Pricing Man; How Price Affects Everything. New York: Springer, 2015.

Lepeyko T. I., Blyznyuk, T.P., (2016) “Generational theory: value-oriented approach”, Бізнес Інформ, vol. 11, no 1, pp. $11-24$.

Mair J., Martí I. (2006), Social entrepreneurship research: A source of explanation, prediction, and delight. Journal of World Business, vol. 41, no. 1, pp. 36 - 44.

Meyer R., Johnson, E.J., (2015) "Empirical generalizations in the modelling of consumer choice", Marketing Science, vol. 14 , no 5, pp. $180-189$.

Morris, H., Hirschman, E., (2012) "The Experiential Aspects of Consumption: Consumer Fantasies, Feeling and Fun", Journal of Consumer Research, vol. 9, no 2, pp. $132-140$.

Neck H., Brushet C., Allen E.. (2009). The Landscape of Social Entrepreneurship. Business Horizons, no.52, pp. 13-19.

Nicholls, A., Cho, A. H. (2006), "Social Entrepreneurship: The Structuration of a Field, Social Entrepreneurship. New Models of Sustainable Change, Oxford University Press, Oxford, no. 18, pp. 99-118

Nyssens, M. (2006). Defining Social Enterprise. Social Enterprise: At the Crossroads of Market, Public Policies and Civil Society. no. 11, pp. 63- 52.

Popov E., Veretennikova A. (2016). Institutional Mechanism for Shaping Social Innovation. Economic and social changes: facts, trends, forecast, no. 5, pp. 73-79.

Sandal, J-U. (2004) Sosialt Entreprenфrskap. Lund University, Sweden, ISBN.ISSN 1101-346X, No. 96, 2004.

Seelos C., Mair J. (2005) Social entrepreneurship: Creating new business models to serve the poor. Business Horizons, vol. 48 , no. 3 , pp. $241-246$.

Slaughter, J.E., Sinar, E.F., Highhouse, S., (2009) "Decoy effects and attribute-level inferences", Journal of Applied Psychology, vol. 84, no 7, pp. $823-828$.

Steyaert C., Katz J. (2004) Reclaiming the space of entrepreneurship in society: Geographical, discursive and social dimensions. Entrepreneurship and Regional Development, vol. 16, no. 3, pp. $179-96$.

Stryjan, Y. (2006): Social Enterprises within a universal welfare state model. Social enterprise at the crossroads of market, public policies and civil society, vol. 11, no. 5, pp. $47-54$.

Swanson L., Zhang D. (2010) The Social Entrepreneurship Zone. Journal of Nonprofit \& Public Sector Marketing, vol. 22 , pp. $71-88$.

Tapsell P., Woods C. (2010) Social entrepreneurship and innovation: Self-organization in an indigenous context. Entrepreneurship \& Regional Development, vol. 22, no. 6, pp. 535 - 556.

Thompson J., Alvy G., Lees A. (2017) Social Entrepreneurship: A New Look at the People and the Potential. Management Decision, vol. 38, pp. $328-338$.

Urban B. (2013) Social Entrepreneurship in an Emerging Economy: A Focus on the Institutional Environment and Social Entrepreneurial Self-Efficacy. Managing Global Transitions, vol. 11, no. 1, pp. 3 - 25.

Wallace, W. (1999). The Sharing of Sovereignty: The European Paradox. Political Studies, vol. 47(3), pp. 503-521.

Weerawardena J., Mort G. (2001) Learning, Innovation and Competitive Advantage in Not-For-Profit Aged Care Marketing: A Conceptual Model and Research Propositions. Journal of Nonprofit \& Public Sector Marketing, vol. 9 , no. 3 , pp. $53-73$.

Zahra S., Gedajlovic E., Neubaum, D., Shulman J. (2009) A typology of social entrepreneurs: Motives, search process, and ethical challenges. Journal of Business Venturing, vol. 24, no. 5, pp. 519 - 532.

\section{About the author}

Elvin OMAROV, Affiliated honorary research fellow in Fil. Dr. Jan U. Sandal Institute; PhD student in Simon Kuznets Kharkiv National University of Economics, Kharkiv, Ukraine. Research interests: social entrepreneurship, business administration, consumer behaviour.

ORCID ID: https://orcid.org/0000-0001-6397-4978 